\title{
Zinc Finger Protein Aiolos
}

National Cancer Institute

\section{Source}

National Cancer Institute. Zinc Finger Protein Aiolos. NCI Thesaurus. Code C80031.

Zinc finger protein Aiolos (509 aa, $\sim 58 \mathrm{kDa}$ ) is encoded by the human IKZF3 gene. This protein is involved in both lymphocyte development and transcription. 